\title{
RE-IMAGINING AFRICANISATION OF SUSTAINABLE EPISTEMOLOGIES AND PEDAGOGIES IN (SOUTH) AFRICAN HIGHER EDUCATION: A CONCEPTUAL INTERVENTION
}

\author{
M. Sebola* \\ e-mail: moffat.sebola@ul.ac.za / https://orcid.org/0000-0002-0903-283X
}

\section{M.J. Mogoboya*}

e-mail: mphoto.mogoboya@ul.ac.za / mphotoj.mogoboya@gmail.com / https://orcid.org/0000-0002$\underline{4218-2215}$

*Department of Languages

University of Limpopo

Sovenga, South Africa

\section{ABSTRACT}

This article aims to foreground the conceptual premise that (South) African academia should be the hub of Afrocentric knowledge production, both at theoretical and practical levels, through the efficacy of both "academic" and "non-academic" intellectuals. We further argue that these intellectuals, undergirded by epistemic desires for organic knowledge production, should be considered germane in the process of Africanising (South) African academia. The Afrocentricity theory, Antonio Gramsci's (1971) and Syed Hussein Alatas' (1977) conceptualisation of intellectuals serve as lynchpins for the conceptual forte of this article.

Keywords: knowledge production, academia, re-imagine, stagnation, sustainable

\section{INTRODUCTION}

Given that academic institutions are "the intellectual landscape" (Oelofsen 2015, 130), it follows that they should play a central role in contributing to sustainable knowledge production. In fact, it would not be baseless to assert that "higher education everywhere is in the business of knowledge production" because higher education institutions house, or at least should house, "the highest concentration of specialised knowledge personnel with the right mix of ideas" (Ogbodo, Efanga and Ikpe 2013, 9). This right mix of ideas can be churned by intellectuals into the production of knowledge that can be translated into "meaningful innovations" (Chetty, Mgutshini and Pienaar 2014, 224), and thus continue to advance the course of human development. "Where it still matters", posits (Mbembe 2016, 39), "the university is perceived as a crucial part of national innovation systems, a source of economically valuable knowledge and, consequently, a key factor of production in globalizing knowledge capitalism". Perkin 
(2006) recognises institutions of higher learning as centres of teaching and learning that play an important role within many advanced civilisations. This essentially means that "knowledge has become a commodity" (Mbembe 2016, 40), which further implies that knowledge drives socio-economic development (Moahi 2009).

Ogbodo et al. $(2013,10)$ states: "Our higher institutions should be the basic think tank of the society in all areas. It should continuously generate ideas and knowledge, and disseminate them, develop skills and abilities in all who seek knowledge within their walls." With this awareness, one would think African universities in general and South African universities in particular, are in the frontline of attestable knowledge production. African universities, however, are generally "ranked lowest in terms of research output" (Moahi 2009, 1); Africa's research profile remains weak (Zeleza 2017). Scholarly research presence, avers Kgautle (2009) (in Moahi 2009), is one of the criteria used in ranking universities. In this article, we conclude that the intellectual efficacy in (South) African academia is the hub from which organic, Afrocentric knowledge should be produced. We propose organic, Afrocentric knowledge production bearing in mind the somewhat crude reality that "the university is being refounded and is being rescaled with the purpose of better turning it into a springboard for global markets in an economy that is knowledge-based, innovation-based" (Mbembe 2016, 38). The global restructuring of higher education, as revealed by Mbembe (2016), requires a parallel reimagination and therefore, restructuring of knowledge production.

The problem, of course, is whether the university itself, through its intellectuals, is reformable and whether the term "intellectual" is credibly and epistemologically definable in the first place. As a starting point, we pose questions which may be instrumental in the "credible" definition of an intellectual in academia, i.e.: What, or rather, who is an intellectual? What are the distinctive features of an intellectual? Are there any criteria for determining distinction(s) between intellectuals and non-intellectuals in academia? What exactly is the role or function of an intellectual in academia? Where or how does an African intellectual feature in the process of the Africanisation of a university? Who should be the custodians of attestable knowledge production in (South) African academia? For whom should knowledge be produced and theorised by (South) African academia? Should (South) African academia integrate knowledge systems or frameworks of the West into their own contexts of knowledge production? Do (South) African academic institutions need to adopt and adapt knowledge from the West? Has the West adopted and adapted any knowledge from Africa to form part of their education system(s)? Is it possible for (South) African academic institutions to collectively produce unified and effective Afrocentric curricula? We wrestle with these questions in an effort to foreground ideological postulations on the causes of what we term "intellectual barrenness" in 
(South) African academia. We also hope to offer some plausible remedial suggestions, in the form of a conceptual intervention, on combating the probability of such barrenness. We are not ignorant, however, of some of the glaring causes of intellectual barrenness in (South) African academia. The next section elucidates more on these causes.

\section{POSSIBLE CAUSES OF INTELLECTUAL BARRENNESS IN (SOUTH) AFRICAN ACADEMIA}

When contextualising material conditions circumscribing sustainable knowledge production in African academia, Imam and Mama (1994) identify several factors. Among those factors are: lack of academic freedom; State repression; intimidation; curtailing and policing of intellectuals; power interruptions; lack of potable tap water; poor funding for research; theoretical or innovative empirical work and the social responsibility of intellectuals. These problems are interrelated and cumulative, assert Imam and Mama (1994), but may be summed up as lack of funding for research, lack of access, poor training, lack of experience, isolation of researchers, paucity of outlets for intellectual interaction and publishing, work burdens (both paid and unpaid), and a repressive intellectual climate. Vastly different levels of research funding from the Department of Higher Education and Training (DHET) in South Africa were cited when DHET convened in 2012, to envision the future of humanities and social sciences. One of the issues raised was that "well-off universities [in South Africa] are made richer and poor universities poorer" (DHET 2012, 10, authors' insertion).

Shai (2019) notes the gatekeeping of knowledge by editors of scholarly journals as a probable hindrance to knowledge production in South African scholarship. Shai (2019) further asserts that, generally, there are quite a few well-established scholars in South Africa who are willing to review papers and provide timeous feedback, especially to prospective scholars. Individualism, selfishness among (South) African academics and competitive rather than cooperative behaviour among higher education institutions may also be responsible for intellectual barrenness (DHET 2012; Shai 2019). This is probably motivated by the fact that universities reward individual success in research over the promotion of innovative and inclusive teaching and learning (Beech, MacIntosh and MacLean 2010; Shai 2016). It is also possible that "knowledge is generated in [South] African universities and research centres but is either disseminated in expensive international journals, or gathers dust in the offices (and computers) of the generators" (Moahi 2009, 1) and thus appear as if no knowledge is produced because of its inaccessibility.

Zeleza (2017) considers the growing disempowerment and undermining of academic autonomy and freedom; casualisation of academics; fragmentation of both academics and 
academic work as a product of institutional, professional, and instructional unbundling of faculty roles as constituting key causes of the current apparent decline in educational quality in institutions of higher learning. Although these are not all the issues related to intellectual barrenness, it suffices to say that they obviously pose constraints to the free, consistent and autonomous production of sustainable knowledge in (South) African academe. Notwithstanding these, we purport that intellectuals in (South) African academia can and should contribute to the generation of "African-grown knowledge" (Moahi 2009, 1) with the sole intention of decolonising and Africanising African academe. By decolonisation we mean "the process that colonised countries go through when they become politically independent from their former colonisers" (Oelofsen 2015, 131). We, together with Louw (2010, 42), generally see Africanisation "as a renewed focus on Africa - reclaiming what has been taken from - and the emergence of a new sense of pride".

We also acknowledge that numerous perspectives on the plausibility of the Africanisation and decolonisation of (South) academia, worthy of serious consideration, may emerge, i.e., (1) the role of higher education in the Africanisation of education (Horsthemke 2004); (2) the need for clarity on whether "decolonisation" is the same as "Africanisation" and the decolonisation of prevalent colonial (apartheid) infrastructure/architecture at South African universities (Mbembe 2016); (3) linguistic imbalances in South African universities (Madadzhe 2019); (4) the entrenchment of the colonial legacy on African education systems and curricula (Mangu 2005); (5) paradigmatic limitations and material constraints; academic and intellectual imperialism in Africa (Imam and Mama 1994); (6) the instrumentality and legitimisation of African philosophy in the project of decolonising the African mind (Oelofsen 2015); (7) the essentialisation and centralisation of African indigenous knowledge systems as philosophical constructs and catalysts for ideas in the Africanisation process (DHET 2012; Le Grange 2007; Mbembe 2016; Oelofsen 2015; Seepe 2000); (8) reclaiming the link between Africa and civilisation that leading European intellectuals denied (Adeleke 2015); (9) reasserting the agency of Africans, re-Africanising the consciousness of Blacks in Africa and the Diaspora, affirming the universality of the African worldview and debunking entrenched historical fallacies, including the negation of African (Black) history and culture (Asante 1987; 1988; $1990 ; 1991 ; 1999 ; 2003 ; 2009) ;(10)$ the primacy of mental decolonisation for the purposes of attaining African development (Kebede 2004); (11) the dilemma of constructing local curricula (which speaks to the social context of Africa), where ideas of the West are still considered superior (Louw 2010); (12) responding to the existence of African scholars whose "scholarly" works espouse Euro-American value systems (Shai 2019). Most of the thematic concerns encapsulated in these perspectives will, as a matter of necessity, compel a serious consideration 
of the content and extent of what is taught and learned in (South) African universities. As a matter of pre-eminence, curriculum reform will be the central thematic anchor on the subject of Africanising and decolonising knowledge production in (South) African academia. The reimagination of the reformation of curricula in (South) African higher education, in the process of legitimising indigenous knowledge production, will find it imperative to change the curriculum Afrocentrically (Asante 1991).

Hence, we submit that Africanisation should be the theoretical lynchpin upon which African intellectuals envision sustainable knowledge production in (South) African universities. The project of Africanisation, although an uphill effort, is not at all impossible, especially when one considers that "all content is adaptable to an Afrocentric approach" (Asante 1991, 171). A case in point is South Africa where the idea of Africanising institutions of higher learning is gaining traction, i.e., in the Universities of South Africa, Kwazulu Natal and Stellenbosch (Louw 2010; Madadzhe 2019). The methodical forte of Africanisation may also be premised on the awareness that in the "past",

"Decolonization created favourable conditions for the production of nationalist historiography as new universities were established, research funds became available, historical associations were formed, journals launched, and publishers scrambled for the latest research findings. Famous schools emerged, most prominently the Ibadan school, which denounced the shortcomings of missionaries and colonial governments ... Nationalist historians chronicled the rise and fall of Africa's ancient states and empires, long-distance trade, migrations, the spread of religions, and critiqued colonial policies, celebrated the growth of nationalism, and reincorporated Egypt and North Africa into the mainstream of African history. The nationalist perspective spread to universities in the global North were African studies programs mushroomed." (Zeleza 2017, 5).

The (past) decolonisation herein referred to by Zeleza (2017) is the $20^{\text {th }}$ century where the nationalist and radical traditions challenged the Eurocentric or imperialist perspectives proving that colonialism was merely an episode, a parenthesis, a footnote and not the sole library of African history. Zeleza reveals that in this phase, there were deliberate efforts to reconstruct the African image and narrative, irrespective of the possibility of being depicted as atavistic by the advocates of Eurocentrism. If there were symptoms of progress towards Africanisation, it then begs the question, what halted the progress? Several responses may be formulated but much of the thematic outlook is likely to encapsulate the concession: "From the 1970s, the fourth phase, the post-independence era, began to unfold from the momentary euphoria of decolonization. Not surprisingly, the nationalist tradition started to face challenges from radical perspectives" (Zeleza 2017, 5). Part of the problem could be that antagonists view the Afrocentric initiative as a Black version of Eurocentricity (Asante 1987). Afrocentricity, as endorsed in this article, "does not condone ethnocentric valorisation at the expense of degrading 
other people's perspectives" (Asante 1991, 172). Another reason for the halt could be that there were not as many advocates of Africanisation who were willing to endure intellectual alienation by those who believe in "European overlordship" (Zeleza 2017, 4). It is possible that the Afrocentric enterprise still receives a backlash (Asante 1991), because there are still people who believe in European overlordship and thus find the idea of Africanising academia unimaginable.

Zeleza speaks about the fourth phase precisely because prior to the summation cited above, he essentially categorised cultures of knowledge production in Africa into four libraries. The four libraries that emerged during the four phases in historiography, which due to spatial limitations will not be dealt with thoroughly here, are: firstly, the ancient era that spawned what Zeleza calls Afro-Christian, Afro-Islamic, and griot libraries; secondly, the slave trade era that gave rise to the colonial library; thirdly, the colonial period when the colonial library was consolidated and the fourth phase (where we are) which is the post-independence era, "during which the four libraries are locked in fierce contestations", respectively (Zeleza 2017, 3). In the post-independence era where there is a synthesis of the four libraries, we are compelled to ask the question: "What are the prospects for a new library to emerge out of the synthesis of these four libraries?" (Zeleza 2017, 3). In response to the question, we should, as a matter of preeminence, begin with an honest acknowledgement that universities that many African countries, including South Africa, inherited from colonisation were (and still are) African in name and location only but the curricula are still dictated by the ex-colonial masters (Mangu 2005). Precisely, "we have universities in Africa, but we don't have African universities" (DHET 2012, 14). Perhaps with the admission, there will be a need to develop an epistemological lynchpin upon which the Africanisation of (South) African academia may be anchored.

In this instance, we realise that the project of Africanisation of (South) African universities necessitates the proposal of Afrocentricity as an alternative "theoretical perspective" (Anderson 2012, 1). Shai $(2019,3)$ concurs: "the politics of scholarship in South Africa and Africa at large can be best understood when studied through the prism of African-centred values, standards, and tools such as Afrocentricity". Afrocentricity, according to Asante (1999, 1-2), is "a critical corrective to a displaced agency among Africans" by "re-centring African minds". Afrocentricity may also be viewed as a paradigm based on the idea that African people should re-assert a sense of agency in thought and practice within the livelihood of Africans, their societal institutions and processes in order to achieve sanity (Anderson 2012; Asante 2009; Shai 2019). Most scholars are agreed that this reassertion of agency and achievement of "sanity" ought to be considered in the light of the impact of the colonial legacy on the African mind and subsequently on African academe (Adeleke 2015; Chetty et al. 2014; Louw 2010; Madadzhe 2019; Mbembe 2016; Mogoboya 2011; Oelofsen 2015). Africanisation of African academe, 
through sustainable knowledge production, cannot be easily imagined without an African philosophy to undergird the whole process; the decolonisation of the African mind and the African intellectual landscape requires an African philosophy (Oelofsen 2015). Sustainable knowledge production in African academe precisely requires systems of knowledge and knowledge production that may be perceived as antithetical to the Western empirical systems (Abodunrin 2016). For Asante (1991), the centricity of Africans in the articulation of their own history and knowledge production is key. Asante $(1991,171)$ avers: "In education, centricity refers to a perspective that involves locating students within the context of their cultural references so that they can relate socially and psychologically to other cultural perspectives" (original italics). We advocate that Afrocentric, organic and functioning intellectuals in academia should be at the forefront in the process of generating "substantive and meaningful" knowledge that also addresses “the African's historical experiences" (Asante 1991, 170).

We also acknowledge that the Africanisation project has two sides (Mbembe 2016), which (South) African academia should consider in the process of Africanising knowledge production. Firstly, there is a need to unambiguously critique the dominant Eurocentric academic models or "epistemic coloniality", that is, "the endless production of theories that are based on European or Euro-American traditions, produced by people who are the only ones accepted as capable of reaching universality" (Mbembe 2016, 36). "Epistemic coloniality" involves "a particular anthropological knowledge, which is a process of knowing about Others -but a process that never fully acknowledges these Others as thinking and knowledge-producing subjects" (Mbembe 2016, 36). The Afrocentric, organic knowledge producer in (South) African academia primarily has this uphill task to execute. Secondly, the Afrocentric, organic knowledge producer must be "capable" of imagining what alternative strategies to Eurocentric models of knowledge production could look like (Mbembe 2016), and theorise sustainable knowledge production from that perspective. In the process of re-imagining what an Africanised university might look like, the Afrocentric, organic knowledge producer may begin by seriously reflecting on the possibilities of what others have begun to imagine as a "pluriversity" instead of a "university" (Mbembe 2016, 36). "By pluriversity, many understand a process of knowledge production that is open to epistemic diversity. It is a process that does not necessarily abandon the notion of universal knowledge for humanity, but which embraces it via a horizontal strategy of openness to dialogue among different epistemic traditions" (Mbembe 2016, 37, original italics). Multiculturalism in education (Asante 1991), may not be a bad idea in this imagination of a pluriversity because it can allow both students and teachers, for example, to see themselves within the content of the curriculum rather than at its margins.

Rethinking is an essential aspect in this whole process of producing sustainable knowledge 
in (South) African academia because we do not want "to fight the battles of the future with outdated tools" (Mbembe 2016, 37), that is if we are willing to envision the possibility of "pluriversalism" in the first place. Irrespective of the contestations and ambivalences that may emerge, we imagine the role and function of Afrocentric, organic and functional intellectuals in academia as critical in the process of sustainable knowledge production. Our ideological premise is that intellectuals in academia attract and sustain a modicum of intellectual credibility and respectability through knowledge production in their respective fields of study. In this instance, we deem it unavoidable to provide a "tentative" definition or at least, a workable description of what is meant by organic and functioning intellectuals in academia.

\section{TOWARDS A DEFINITION AND ROLE OF AN INTELLECTUAL IN ACADEMIA}

We believe, to begin with, that "the central thesis on the role of the academic is the production of knowledge" (Aldama 2008, 110). Tied to this role is the ability "to identify new forms of struggle and solidarity in places we never thought to look" (Denning 2004, 233-234). It is through this alertness that an intellectual in academia can provide theoretical, practical and balanced premises upon which the socio-political, socio-cultural, socio-economic and sociohuman development can be founded. Our opinion is that substantive knowledge production can “prevent intellectual assets [in academia] from decay" (Bhojaraju 2005, 38, authors' insertion). Academics, in our opinion, are positioned as "intellectual assets" within the academic domain, and much of what validates their presence in the domain is their intellectual efficacy. We concur with Ogbodo et al. $(2013,10)$ that academics should be "the vanguard of societal response to emergent political, economic, social and environmental problems" because "the advancement of mankind has, through the ages, been knowledge-driven, and knowledge should be the basic product of universities". Lack of knowledge production may arguably render intellectuals in academia irrelevant in their respective fields of study. We are quick to concede that production of knowledge in academia may not necessarily be limited to one's field of study only, knowledge production may and should also be "interdisciplinary, multidisciplinary or transdisciplinary" (Shai 2019, 3). The re-imagination of sustainable knowledge production in (South) African academia needs to involve "the radical refounding of our ways of thinking and a transcendence of our disciplinary divisions" (Mbembe 2016, 37 original italics). This refounding of our ways of thinking beyond disciplinary divisions is essential, especially when considering factors such as: "a massive reorganisation of knowledge production, dissemination and consumption" which is "partly evident in the expansion and emergence of new disciplines, sub-disciplines, and inter-, trans- and multi-fields of study" (Zeleza 2017, 8). Zeleza further notes that there are remarkable shifts in global knowledge hegemonies and hierarchies. Parts of 
these shifts are linked to the fact that transformational modes of knowledge production, dissemination and consumption are undergoing changes, facilitated by the rise of new information and communication technologies (Zeleza 2017). The pedagogical opportunities and challenges of technology-enhanced scholarly knowledge production cannot be overlooked in this article but a thorough discussion deserves a separate paper. Where we also wish to locate and emphasise our ideological outlook on the issue of knowledge production in (South) African academia is specifically on the role and the types of intellectuals in academia (which we cover in the subsequent section).

\section{Definition and role of intellectuals}

An intellectual is defined by Federspiel $(1999,46)$, as an individual who formulates generalisations or concepts about underlying values, direction or effort of any association, society, nation or humanity in general. Federspiel (in Niam 2010, 290) further identifies intellectuals with the production of materials that serve to prompt society in certain directions and provide a rationale for that undertaking. For Dimitriou (2017, 9-10), intellectuals may be "envisioned as powerful figures, capable of ameliorating the world". Dimitrou maintains that "because of their position and knowledge, intellectuals are expected to provide criticism on pressing matters and lead the way to improvement" (2017, 4). Michels (1949) regards intellectuals as people who possess knowledge, or in a narrow sense, those whose judgment, based on reflection and knowledge, derives less directly and exclusively from sensory perception than in the case of non-intellectuals. In an epoch where "knowledge is perpetually in motion, an intellectual should be an individual who is challenged to engage and reflect on the condition of education system(s) and philosophies of research, teaching and learning of the institution(s) to which he or she swears allegiance" (Edwards et al. 2013, 5). Thus, an intellectual is positioned in academia as an agent and conduit of ideas, both modern and conservative. An intellectual is "someone whose being is staked on a critical sense, a sense of being unwilling to accept easy formulas, or ready-made clichés ..." (Said 1994, 23). Chomsky (1967) purports that intellectuals ought to have an active role in society because they have the power to exercise pressure on important public matters and to guide people towards the most beneficial direction. From this understanding emerges the assumption that an intellectual in academia ought to participate in the development of both the academic institution and community to which they belong through knowledge production. In this sense, intellectuals labour to produce ideas and ideals that stimulate growth and development in different aspects of society. 


\section{Types of Intellectuals}

Gramsci (1971) and Alatas (1977) categorise intellectuals into: traditional intellectuals and organic intellectuals, and functioning and non-functioning intellectuals, respectively. When distinguishing traditional intellectuals from organic intellectuals, Gramsci highlights that traditional intellectuals are often a product of the current dominating regime, by which he means that they attain some degree of authority and possess a caste-like position in society. Traditional intellectuals are linked to tradition and to past intellectuals; those who are not directly linked to the economic structure of their society and, in fact, conceive of themselves as having no basis in any social class (Ramos 1982). According to Gramsci (1971), traditional intellectuals function to maintain the status quo within the current economic, social and political strata and consequently occupy a "negative position" to the subaltern group (Chetty et al. 2014, 236). Organic intellectuals, on the other hand, emerge as an integral element of transformation for Gramsci (Chetty et al. 2014) and thus are a different category of intellectuals for him because they are more directly related to their society (Ramos 1982). Organic intellectuals, according to Gramsci, are situated in the popular movement whose function is to articulate the values and commitments that bind the group together and are in this way aligned to grass-roots participants in knowledge production. Organic intellectuals are defined by the functions assigned to them by the social group they represent (Chetty et al. 2014). Organic intellectuals are thus involved in the lives of the communities they serve because they engage their communities in their knowledge production. Furthermore, intellectuals are classified into functioning and nonfunctioning intellectuals. A description of a non-functioning intellectual may assume primacy here. According to Alatas (1977), a non-functioning intellectual (even when "educated"), is passive mentally. To begin with,

\footnotetext{
"Non-functioning intellectuals accept what they are taught uncritically, they do not exert themselves to thinking about different problems over a span of years and they are not emotionally committed to the intellectual pursuit. Non-functioning intellectuals do not yearn for intellectual discussions because they feel no need for them. They do not spend time reading on serious subjects and are incapable of forming an opinion beyond what is obvious to most people" (Alatas 1977, $15)$.
}

Although we are quick to accord due respect to academics' possession of a degree or degrees, we also concede that "knowledge of a certain subject or the possession of a degree does not make a person an intellectual, although these often coincide" (Alatas 1977, 8). Alatas purports that there are many degree holders who do not engage in developing their field or in trying to find solutions to specific problems within it. This is not surprising, seeing that "it is not uncommon in certain universities of South Africa to find professors who cannot profess 
knowledge" (Shai 2019, 5). Such degree holders, particularly if they classify themselves as "academics" are to us, non-functioning intellectuals. We also do not dispute that a person with no academic qualifications can be an intellectual (Alatas 1977), an argument also worthy of an independent paper. On functioning intellectuals, Alatas (1977) argues that they manifest social characteristics (succinctly captured by Niam 2010, 291), namely:

"(1) they are recruited from all classes though in differing proportions; (2) they are to be found supporting or opposing various cultural or political movements; (3) their occupation on the whole is as non-manual beings for the most part writers, lecturers, poets, journalists, etc.; (4) to a certain extent they remain at a distance from the rest of society, mixing in a group of their own; (5) they are not merely interested in the purely technical and mechanistic side of knowledge: ideas about religion, the good life, art, nationalism, planned economy, culture and the like belong to their world of thought; (6) the intellectual group has always been a small proportion of society."

An elucidation on each characteristic is improbable in this article but what is notable in the characteristics listed above is that, functioning intellectuals possess a "high quality of intellectual behaviour" (Pratiknya 1986, 4) and are distinguished by a mode of thought, an ideological outlook, that "expresses both their world-view and cultural values" (Sardar 1979, 67). Abdillah $(1997,18)$ adds that an important characteristic in the identification of a functioning intellectual is the ability to express "systematic ideas in responding to social problems". Although we find Alatas' characterisation of intellectuals in society enlightening, we disagree, however, that intellectuals necessarily remain at a distance from the rest of society. In the next section, we discuss how intellectuals, in a firm partnership with society (specifically the subaltern), can contribute significantly to the generation of sustainable knowledge production. We also believe that functioning intellectuals in academia can and should express their systematic ideas in response to social and societal problems while being committed to the academic values of their institutions and immediate communities. For polemical reasons, we propose that the re-imagination of sustainable knowledge production in (South) African academia requires the agency of Afrocentric, organic and functional intellectuals in order for it to substantively materialise.

\section{The necessity of organic and functional intellectuals in sustainable knowledge production}

As a starting point, we propose that the process of reimagining sustainable knowledge production in (South) African academe cannot exclude the necessity and agency of Afrocentric, organic and functioning intellectuals. A pro-intellectual and Afrocentric ethos as a thematic anchor can serve a significant purpose in the institutionalisation and Africanisation of 
knowledge production systems. Our belief is that Afrocentric, organic and functioning intellectuals are better positioned to "pay attention to their environment, continuously improve their quality of belief [in] and devotion [to knowledge production, dissemination and consumption], and improve their thinking ability" (Niam 2010, 292, authors' insertion). We believe Afrocentric, organic and functioning intellectuals deliberately and consistently deepen their understanding of a variety of Afrocentric tenets of knowledge because of their incorporation of the subaltern's grassroots perspectives. Not only that, we also envision Afrocentric, organic and functioning intellectuals in academia as possessing the ability to critique the very system from which they produce knowledge in order to produce substantive "knowledges" (Zeleza 2017,7). Furthermore, Afrocentric, organic and functioning intellectuals do not distance themselves from their communities. On the contrary, they engage their communities in critiquing the composition, consumption and dissemination of their knowledge. It is through this presumed ability to critique the composition of their own knowledge and that of society in general, that the idea of Africanising universities by Afrocentric, organic and functioning intellectuals becomes substantially plausible. An Afrocentric, organic and functioning intellectual is best positioned to also participate in what Wilson (1994, viii) regards as "cultural functionalism" (an essential aspect in the project of Africanisation), which he defines as, “... a theory of culture which analyses the interrelation and interdependence of patterns and institutions within a cultural complex or social system, and which emphasizes their interaction in the maintenance of socio-cultural unity or in meeting biosocial requirements". An Afrocentric, organic and functioning intellectual is never content with merely recycling knowledge that has been circulating for centuries (Ogbodo et al. 2013, 11). On the contrary, an Afrocentric, organic and functioning intellectual highlights relevant and paradigmatic grounds for present-day academia through "ideological enculturation" (Owusu 2005, vii) (in Arthur 2010), using the very knowledge that has been circulating for centuries. This ideological enculturation may be fortified by a meaningful interaction between intellectuals in academia and subaltern communities.

\section{Epistemic intersections of knowledge production between academics and endogenous communities}

Efforts channelled towards the re-imagination of sustainable knowledge production in (South) African academe should bear in mind Waghid's (2002) postulations on how higher education in South Africa can become pedagogically and socially more relevant. Waghid $(2002,457)$ proposes the idea of a reflexive praxis which allows for the integration of Mode 1 and Mode 2 forms of knowledge production. Mode 1 form of knowledge production entails disciplinary 
knowledge whereas Mode 2 form of knowledge production encompasses the socially distributed knowledge. Both modes are critical because when disciplinary knowledge is supplemented by socially distributed knowledge, intellectuals in academia are best positioned to incorporate indigenous knowledge systems in their production of knowledge. Chetty et al. $(2014,234)$, on the other hand, propose three constructs that are critical to the dimension of knowledge production in academia. Those constructs are: Construct 1 (Organic intellectuals), Construct 2 (Subaltern knowledge) and Construct 3 (Co-producing organic knowledge). This article concurs with Waghid (2002) and Chetty et al.'s (2014) postulations. We further centralise the theorisation of African indigenous knowledge systems in the process of producing, consuming and disseminating knowledge in (South) African academia. Theorisation implies formulation of academic discourses, incorporation of modern technology and centralisation of African ways of thinking into ideological and pedagogical frameworks. These ideological and pedagogical frameworks ought to be designed in such a way that they can generate substantial and researchable African content in (South) African academe rather than the marginalisation and subversion of African ways of knowledge generation. This will be improbable if African indigenous knowledge is treated as an appendix to the Eurocentric content, taught in (South) African institutions of higher learning. African indigenous knowledge systems should be prioritised in the (South) African higher education sphere where extraction and theorisation of African organic knowledge essentially involves the agency of the (South) African community, and not just intellectuals in academia. Chamberlain (2003) consents that indigenous knowledge systems deserve to be given more priority within higher education. Indigenous knowledge (and traditional knowledge) is "the totality of all knowledge and practices established on past experiences and observation that is held and used by a people" (Masango 2010, 74). (For a detailed discussion on indigenous and traditional knowledge, see Masango 2010). Our submission is that part of the (South) African academia's inability to produce and theorise Africanised and decolonised, critical and sustainable knowledge is that "the subaltern still struggles for agency, power and social mobility" in (South) African academia (Chetty et al. 2014, 234). If we are to better reimagine sustainable knowledge production in South African academic sphere(s), we cannot ignore ideological outlooks such as Gramsci's (1971) theorising of organic knowledge production. Gramsci recognises the role that the subaltern can play in the creation of knowledge. It is our belief that (South) African communities possess organic knowledge production systems and the knowledge they produce can be systematised into pedagogies in academia for the purposes of decolonising (South) African universities. Chetty et al. $(2014,226)$ cherish this view: 
"Universities engage with communities and with stakeholders and one of the perceived benefits of these engagements relates to the demonstration of the benefits of higher education to the wider population. These benefits may include making academic knowledge and expertise available to communities and co-creating knowledge with communities and industry."

Chetty et al. (2014) further assert that academia has the potential to make more meaningful contributions to society if its knowledge production is negotiated between academics and recipient communities. A disjuncture between academia and the community will always perpetuate a misalignment between the role and purpose of academia and the community it should serve. A stable relationship between intellectuals and the communities they serve makes room for the mode of knowledge production that Pettigrew (2001) regards as "co-production". The idea of co-production of knowledge is that "academics and practitioners work together through engagement and dialogue to find practical solutions to real world problems, which simultaneously inform theory" (Chetty et al. 2014, 227).

\section{POSTULATIONS ON GENERATING AND SUSTAINING KNOWLEDGE PRODUCTION IN (SOUTH) AFRICAN ACADEMIA}

Whatever paradigms are postulated for growth and development in (South) African academia, they need to value the significance and the role of the intellectual, which might even necessitate the reconceptualisation and clear articulation of intellectuals and their role in academia (Chumbow 2005). In such paradigms, a theoretical and applicable framework for the production and systematisation of Africanised pedagogy in (South) African higher education is germane. Waghid $(2002,459)$ contends that transformation in higher education entails "a process of new knowledge production, reflexive action, which means seeing new problems and imagining new ways of approaching old problems ...". In shaping the institutional framework for sustainable knowledge production in (South) African academia, intellectuals need to demonstrate their value and presence through intellectual efficacy. The issue of language will also prove itself essential in this whole project because we cannot imagine sustainable knowledge production in (South) African academia without theoretically and practically elevating indigenous languages in our envisioned pedagogies. In an effort to address the questions of language, we may, for example, begin with envisioning undergraduate degrees in Tshivenda, Xitsonga, Northern Sotho, etc., and have graduates in Afrocentric pedagogies. If we can, for example, have a degree in "Biology," we can also have a degree in, say, "Africology", whatever that may mean. "This is to make a simple proposition: let us truly immerse ourselves in African and global histories of knowledge" (Zeleza 2017, 2). Of course, we will have to guard against the possibilities of balkanisation and the employment of reductionist approaches in the design of Afrocentric 
curricula across our regions. Generating an Afrocentric epistemology in (South) African academia will require that we move beyond merely critiquing Eurocentric pedagogies to the theorisation and conceptualisation of endogenous frameworks that rise to international impact. Production and systematisation of endogenous knowledge in (South) African academe essentially requires an interlocking allegiance between "academic" intellectuals and "nonacademic" intellectuals. We will also have to address questions of whether or not it is possible for the (South) African intellectual framework to protect all types of indigenous traditional knowledge against exploitation since financial considerations are the basis for the protection of indigenous traditional knowledge (Masango 2010). Furthermore, we will have to bear in mind that "knowledge production unfolds in the shifting intersections of political economy, historical geography, and epistemological and ontological constructs" (Zeleza 2017, 3). In the same context, we must also urge ourselves to "take seriously the studying of African and world histories, not to apologize for Africa's centrality certainly to itself and also to the world" (Zeleza 2017, 2).

\section{CONCLUSION}

A project that seeks to reimagine sustainable knowledge production in (South) African academia "must begin by understanding the variety, development, and intersections of Africa's multiple libraries" (Zeleza 2017, 2). Such a process, although Afrocentric or ethnocentric in outlook, "must go beyond Afrocentric injunctions of proclaiming Africa's eternal difference and recognize the enduring and complex conversations of cultures and ideas within Africa itself and between the continent's societies and civilizations and those of other continents beyond Europe" (Zeleza 2017, 2). We must imagine sustainable knowledge production in (South) African academia bearing in mind the historical geographies, the epistemological and ontological battles that may arise because of the inevitable manifestation of various tenets characterising such a process. Whatever the challenges and oppositions, the process of sustainable knowledge production in (South) African academia will not be attainable without the academics' intellectual efficacy, the reconceptualisation, the clear articulation of their role in academia and the appropriate centrality of the African person (Asante 1987).

\section{REFERENCES}

Abdillah, M. 1997. Responses of Indonesian Muslim intellectuals to the concept of democracy (19661993). Hamsburg: Abera Network.

Abodunrin, F. 2016. African literature and indigenous religion: A study of Wole Soyinka's Death and the King's Horseman and D.O. Fagunwa's Adiitu Olodumare Imbizo 7(2).

Adeleke, T. 2015. Africa and Afrocentric historicism: A critique. Advances in Historical Studies 4: 200- 
215. http://dx.doi.org/10.4236/ahs.2015.43016 (Accessed 22 May 2019).

Alatas, S. H. 1977. Intellectuals in developing societies. London: Frank Cass.

Aldama, F. L. 2008. Why humanities matter: A commonsense approach. Texas, Austin: University of Texas Press.

Anderson, R. 2012. Molefe Kete Asante: The Afrocentric idea and the cultural turn in intercultural communication studies. International Journal of Intercultural Relations: 1-10. http://dx.doi.org./10.1016/j.ijintrel.2012.08.005. (Accessed 18 May 2020).

Arthur, J. A. 2010. African diaspora identities: Negotiating culture in transnational migration. United Kingdom: Lexington Books.

Asante, M. K. 2009. Erasing racism: The survival of the American nation. Thousand Oaks, CA: Sage Publications.

Asante, M. K. 2003. Afrocentricity: The theory of social change. Chicago: African American Images.

Asante, M. K. 1990. Kemet, Afrocentricity and knowledge. Trenton, NJ: Africa World Press.

Asante, M. K. 1991. The Afrocentric idea in education. Journal of Negro Education 60: 170-180. http://dx.doi.org/10.2307/2295608 (Accessed 18 May 2020).

Asante, M. K. 1999. The painful demise of Eurocentrism: An Afrocentric response to critics. Trenton, NJ: Africa World Press.

Asante, M. K. 1988. Afrocentricity. Trenton, NJ: Africa World Press.

Asante, M. K. 1987. The Afrocentric idea. Philadelphia, PA: Temple University Press.

Beech, N., R. MacIntosh and D. MacLean. 2010. Dialogues between academics and practitioners: The role of generative dialogue encounters. Organization Studies 31(9): 1341-1367.

Bhojaraju, G. 2005. Knowledge management: Why do we need it for corporates. Malaysian Journal of Library \& Information Science 10(2): 37-50.

Chamberlain, J. E. 2003. If this is your land, where are your stories? Finding common ground. Toronto: Alfred A. Knopf Canada.

Chetty, D., T. Mgutshini and S. Pienaar. 2014. Towards contextually relevant epistemology of knowledge production in teaching and learning in the humanities. Alternation 21(2): 223-247.

Chomsky, N. 1967. The responsibility of intellectuals. The New York Review of Books 8(3). https://chomsky.info/19670223/\#fn21 (Accessed 23 May 2019).

Chumbow, B. S. 2005. The language question and national development in Africa. In African intellectuals: Rethinking politics, language, gender and development, ed. T. Mkandawire. London: CODESRIA.

Denning, M. 2004. Culture in the age of three worlds. White Paper 3: A Programme for the Transformation of Higher Education. Government Gazette No. 18207, 15 August. Pretoria: Government Printers.

Department of Higher Education and Training. 2012. The future of humanities and social sciences in South African universities. Conference Convened by the Department of Higher Education and Training, Birchwood Conference Centre, Johannesburg, South Africa, 28-30 March: i-45.

DHET see Department of Higher Education and Training.

Dimitriou, A. 2017. The history man and submission: The figure and role of the intellectual in times of crisis and the role of the female characters in the novels' critique of the progressive male academics. MA. Dissertation, University of Leiden.

Edwards, P. N., S. J. Jackson, M. K. Chalmers, G. C. Bowker, C. L. Borgman, D. Ribes, M. Burton and S. Calvert. 2013. Knowledge infrastructures: Intellectual framework and research challenges. Ann Arbor: Deep Blue. http://hdl.handle.net/2027.42/97552 (Accessed 22 May 2019).

Federspiel, H. M. 1999. Muslim intellectual in Southeast Asia. Studia Islamika Vol. 6: (1).

Gramsci, A. 1971. Antonio Gramsci: Selections from the prison notebooks. edited and translated by Q. 
Hoare and G. N. Smith. London: Lawrence and Wishart.

Horsthemke, K. 2004. Knowledge, education and the limits of Africanisation. Journal of Philosophy of Education Society of Great Britain 38(4): 570-587.

Imam, A. and A. Mama. 1994. The role of academics in limiting and expanding academic freedom. In Academic freedom in Africa, ed. M. Mamdani and M. Diouf. London: CODESRIA.

Kebede, M. 2004. African development and the primacy of mental decolonisation. Africa Development XXIX (1).

Le Grange, L. 2007. Integrating western and indigenous knowledge systems: The basis for effective science education in South Africa. International Review of Education 53: 577-591.

Louw, W. 2010. Africanisation: A rich environment for active learning on a global platform. Progressio 32(1): 42-54.

Madadzhe, R. N. 2019. Using African languages at universities in South Africa: The struggle continues. Stellenbosch Papers in Linguistics Plus Vol. 58: 205-218.

Mangu, A. M. B. 2005. Towards the African university in service of humanity: Challenges and prospects for Africanisation at the University of South Africa. Paper for the Seminar on Africanisation, organised at the University of South Africa, 3 March.

Masango, C. A. 2010. Indigenous traditional knowledge protection: Prospects in South Africa's intellectual property framework? South African Journal Library \& Information Science 76(1): 7480.

Mbembe, A. J. 2016. Decolonizing the university: New directions. Arts \& Humanities in Higher Education 15(1): 29-45.

Michels, R. 1949. Intellectual. In Encyclopaedia of Social Sciences. New York: Macmillan.

Moahi, K. H. 2009. Institutional repositories: Towards harnessing knowledge for African development. Paper presented at First International Conference on African Digital Libraries and Archives (ICADA-1), Addis Ababa, Ethiopia, 1-3 July, pp:1-10.

Mogoboya, M. J. 2011. African identity in Es'kia Mphahlele's autobiographical and fictional novels: A literary investigation. Ph.D. Thesis, University of Limpopo.

Niam, K. 2010. The discourse of Muslim intellectuals and "ULAMA" in Indonesia: A historical overview. Journal of Indonesian Islam 4(2): 287-316.

Oelofsen, R. 2015. Decolonisation of the African mind and intellectual landscape. Phronimon 16(2): $130-146$.

Ogbodo, C. M., S. I. Efanga and U. G. Ikpe. 2013. Knowledge production in higher education: Policies and practices in Nigeria.

Perkin, H. 2006. History of universities: International handbook of higher education. London, UK: Springer International.

Pettigrew, A. M. 2001. Management research after modernism. British Journal of Management 12 (1):561-570.

Pratiknya, A. H. 1986. Anatomi Cenderkiawan Muslim: Protret Indonesia. In Islam Indonesia, ed. M. Amin Rais. Suatu Ikhtiar Mengaia Diri. Jakarta: Rajawali.

Ramos, V. 1982. The concepts of ideology, hegemony, and organic intellectuals in Gramsci's Marxism. Encyclopaedia of Anti-Revisionism. https://www.marxists.org/history/erol/periodicals/ theoretical-review/19822301.htm (Accessed 17 May 2020).

Said, E. C. 1994. Representations of the intellectual. New York: Vintage Books.

Sardar, Z. 1979. The future of Muslim civilisation. London.

Seepe, S. 2000. Africanisation of knowledge: Exploring mathematical and scientific knowledge embedded in African cultural practices. In African voices in education, ed. P. Higgs, N.C.G. Vakalisa, T.V. Mda and N.T. Assie-Lumumba, 118-138. Lansdowne: Juta. 
Shai, K. B. 2019. The death of scientific knowledge in [South] Africa: An Afrocentric response to M. P. Sebola. Journal of Public Affairs: 1-7.

Shai, K. B. 2016. An Afrocentric critique of the United States of America's foreign policy towards Africa: The case studies of Ghana and Tanzania, 1990-2014. Ph.D. Thesis, University of Limpopo.

Waghid, Y. 2002. Knowledge production and higher education transformation in South Africa: Towards reflexity in university teaching, research and community service. Higher Education 43: 457-488.

Wilson, H. S. 1994. African decolonization. London: Edward Arnold.

Zeleza, P. T. 2017. The decolonization of African knowledges. Essay specially prepared for the $9^{\text {th }}$ Africa Day Lecture, University of the Free State, Bloemfontein, South Africa, 1-10. 